\title{
ENSO effects on primary productivity in Southern Atacama desert
}

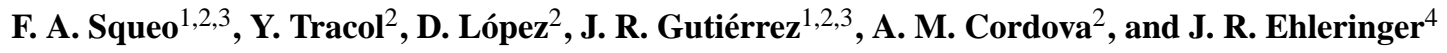 \\ ${ }^{1}$ Departamento de Biología, Facultad de Ciencias, Universidad de La Serena, Casilla 599, La Serena, Chile \\ ${ }^{2}$ Centro de Estudios Avanzados en Zonas Áridas (CEAZA), Casilla 599, La Serena, Chile \\ ${ }^{3}$ Instituto de Ecología y Biodiversidad (IEB), Universidad de Chile, Casilla 653, Santiago, Chile \\ ${ }^{4}$ Department of Biology, University of Utah, USA
}

Received: 7 August 2005 - Revised: 31 January 2006 - Accepted: 2 February 2006 - Published: 3 March 2006

\begin{abstract}
In the winter-rain southern Atacama Desert of the Coquimbo Region of Chile, El Niño - Southern Oscillation (ENSO) events modulate primary productivity. In this region, there are important changes in water availability between La Niña (dry) and El Niño (rainy) years. Using interannual comparisons of LANDSAT images from $30^{\circ}$ to $31^{\circ} \mathrm{S}$ latitude, we observed changes in primary productivity between dry and rainy years at the regional level. There were also significant, negative correlations between productivity and elevation, with changes occurring first at low elevation during rainy years. The limiting factors to dryland vegetation primary productivity is different in regard to elevation. Rain during an El Niño year is the main factor that explains the increase in primary productivity at low elevation, while lower temperatures reduce and delay the net primary productivity at mid elevation.
\end{abstract}

\section{Introduction}

El Niño - Southern Oscillation (ENSO) events have contrasted effects on precipitation regimes in different world regions, either increasing or decreasing rainfall. In the western coastal regions of the Americas, an ENSO event is associated with increased precipitation (Allan et al., 1996; Montecinos and Aceituno 2003). This increase in precipitation enhances plant productivity in terrestrial ecosystems; this effect is especially dramatic in desert ecosystems where water is the main limiting factor to plant productivity (Holmgren et al., 2006). An ENSO event could be considered a quasi-periodic phenomenon, with a periodicity of three to seven years, and a magnitude modulated by the interdecadal oscillations (El Viejo/La Vieja) (Cai et al., 2004).

In addition to precipitation, other climatic factors such as temperature, coastal fog and atmospheric thermal inversion could be modified during El Niño years, and the reverse situ- ation could also be presented during La Niña years (Allan et al., 1996).

There is evidence that ENSO events have occurred for 10000 years. Vegetation has evolved under environmental pressure, and could be considered an integral natural phenomenon (Rosenthal and Broccoli, 2004; Squeo et al., 2001).

An El Niño event with a temperature anomaly $+0.5^{\circ} \mathrm{C}$ in Niño Region 3.4 (bounded by $120^{\circ} \mathrm{W}-170^{\circ} \mathrm{W}$ longitude and $5^{\circ} \mathrm{S}-5^{\circ} \mathrm{N}$ latitude) (Trenberth, 1996, 1997) is teleconnected with an increase in precipitation in north-central Chile $\left(30^{\circ}-\right.$ $35^{\circ} \mathrm{S}$ latitude), with a delay of 6 months. During El Niño episodes there is a trend of above-average precipitation between $30^{\circ}$ and $35^{\circ} \mathrm{S}$ latitude in winter (June to August), while a trend of below-average precipitation is characteristic during La Niña events (Montecinos and Aceituno, 2003). Increase in plant productivity during rainy El Niño years has been reported for coastal desert ecosystems in north-central Chile (Vidiella et al., 1999; Olivares and Squeo, 1999; Holmgren et al., 2006). Most of the reports of El Niño effects are qualitative, such as "the flowering desert" (Dillon et al., 1996). However, few works have the possibility to compare effect on plant productivity in all the climatic condition during an ENSO cycle, including La Niña dry years. In other cases, the observations have been realized in small areas or considering a few groups of plants.

High definition satellite images allow us to determine plant productivity on a regional to local scale concurrently, without the problem of accessibility. Comparison between seasons or years, and between different geographic regions are also possible, allowing for a better understanding of La Niña and El Niño effects in plant productivity.

The main goal of this study is to evaluate the primary productivity of two contrasting years associated with La Niña and El Niño events in low and midland areas of north-central Chile, using the soil-adjusted vegetation index (SAVI; Huete 1988). 

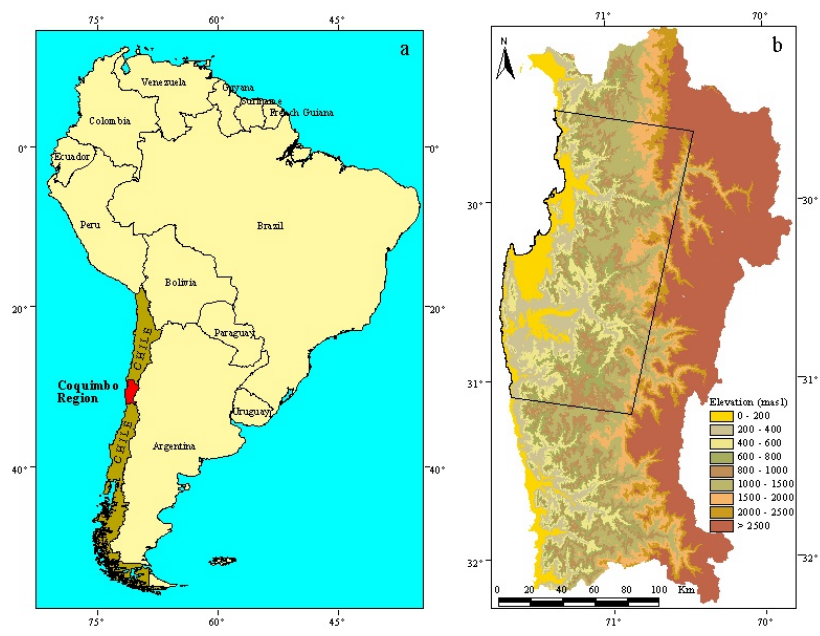

Fig. 1. Study area and LANDSAT scene: (a) Coquimbo Region (Chile) in South America, (b) elevation gradient in Coquimbo Region, with LANDSAT image scheme.

\section{Methods}

\subsection{Study zone}

Shrubland vegetation dominates the semi-arid zone located between 29 and $32.2^{\circ} \mathrm{S}$ latitude and $70^{\circ}$ and $72^{\circ} \mathrm{W}$ longitude at the southern part of the Atacama Desert, in the Coquimbo Region of Chile (Fig. 1). Approximately $75 \%$ of the Coquimbo region is considered lowland (0-1000 ma.s.l.) and midland (1000-2000 ma.s.l.) shrubland, while agricultural areas represent less than $3 \%$.

Rainfall occurs in an exclusive monomodal pattern centered during the winter months in the southern hemisphere (June to September) (Squeo et al., 2004). Annual precipitation measurements from the meteorological station El Romeral (1956-2003), located in the coastal dryland ( $29^{\circ} 43^{\prime} \mathrm{S}$ latitude, $71^{\circ} 15^{\prime} \mathrm{W}$ longitude, $300 \mathrm{~m}$ a.s.l.), show an average of $82.9 \mathrm{~mm}$ ( $76.5 \mathrm{~mm}$ in the last 30 years), with rainy years associated to ENSO events (Squeo et al., 2006). The annual precipitation and precipitation anomaly values for El Romeral were $34.1 \mathrm{~mm}$ and -0.59 , respectively, in 1999 , and $144.5 \mathrm{~mm}$ and 0.73 , respectively, in 2002 . The annual average of the Multivariate ENSO Index (MEI) (Wolter, 1987; Wolter and Timlin, 1998) for the study years were $-0.82 \pm 0.07$ ( \pm SE) in 1999 (a La Niña year) and $0.78 \pm 0.13$ in 2002 (an El Niño year) (data from http://www.cdc.noaa. gov/people/klaus.wolter/MEI/).

\subsection{Landsat scenes process}

We used a set of LANDSAT images from position Path 001, Row 81 that focuses on the coastal to pre-alpine area of the Coquimbo Region (Fig. 1b). The images were taken between spring and summer of a La Niña year (1999-2000) and an El Niño year (2002-2003) (Table 1). All the images were previously processed using geometric and atmospheric
Table 1. Dates of the images Landsat TM used in this study.

\begin{tabular}{ll}
\hline La Niña 1999-2000 & El Niño 2002-2003 \\
\hline 28 September 1999 & 20 September 2002 \\
7 November 1999 & 7 November 2002 \\
10 January 2000 & 26 January 2003 \\
14 March 2000 & 15 March 2003 \\
\hline
\end{tabular}

corrections with ENVI 4.1 (Chuvieco, 1990; Chavez, 1996; Richards and Jia, 1999; ENVI, 2002; Chander and Markham, 2003). According to Chander and Markham (2003), it is expected that a radiometric accuracy of $\pm 5 \%$ could be obtained by reprocessing raw archival data with these lifetime calibration updates. The Dynamic Ranges are obtained from Spectral Radiances, LMIN and LMAX in $\mathrm{W} /\left(\mathrm{m}^{2} \mathrm{sr} \mu \mathrm{m}\right)$ for LANDSAT-5 and LANDSAT-7 (Chavez, 1996; Chander and Markham, 2003).

To reduce the influence of the soil type below the vegetation, we calculated the Soil Adjusted Vegetation Index (SAVI) using ENVI 4.1 and applied it to eight LANDSAT images as a productivity index (Huete, 1988)(Eq. 1):

$\mathrm{SAVI}=(1+\mathrm{L})(\mathrm{NIR}-\mathrm{RED}) /(\mathrm{NIR}+\mathrm{RED}+\mathrm{L})$

Where NIR = near infrared (band 4, 0.7-1.1 $\mu \mathrm{m}$ ), $\mathrm{RED}=\mathrm{red}$ (band 3, 0.6-0.7 $\mu \mathrm{m}$ ), and $\mathrm{L}$ is a parameter to minimize the soil influence (ranging from 0 to 1 ). Its value, as determined for arid zones by Huete $(1985,1988)$, is 0.5 . According to Huete (1988), SAVI is the best index used to characterize the arid zone vegetation, knowing the sparse distribution of vegetation between bared soil patches.

For each month, we calculated the difference between images of a La Niña year and an El Niño year (delta SAVI), using ArcView 3.3 with Spatial Analyses module 2.0 (ESRI 1996). The delta SAVI averages for each altitude range were obtained using a digital elevation model for the area. The delta SAVI values were between +3 and -3 units.

Natural grassland and shrubland (i.e., dryland) areas were identified using the Land Use and Vegetation Spatial Database (CONAF, 2004). The original area of the LANDSAT images was $15166.11 \mathrm{~km}^{2}$, and dryland comprised $14044.27 \mathrm{~km}^{2}$ of that area. Irrigated and cultivated land was excluded.

Using LANDSAT, the absolute surface (brightness) temperature for each image was calculated (Chuvieco, 1990; Raed, 2003) using 6L and $6 \mathrm{H}$ bands $(10.4-12.5 \mu \mathrm{m})$ and ArcView 3.3 with Spatial Analyses module 2.0 (ESRI, 1996). The emissivity is corrected according to Chander and Markham (2003). 

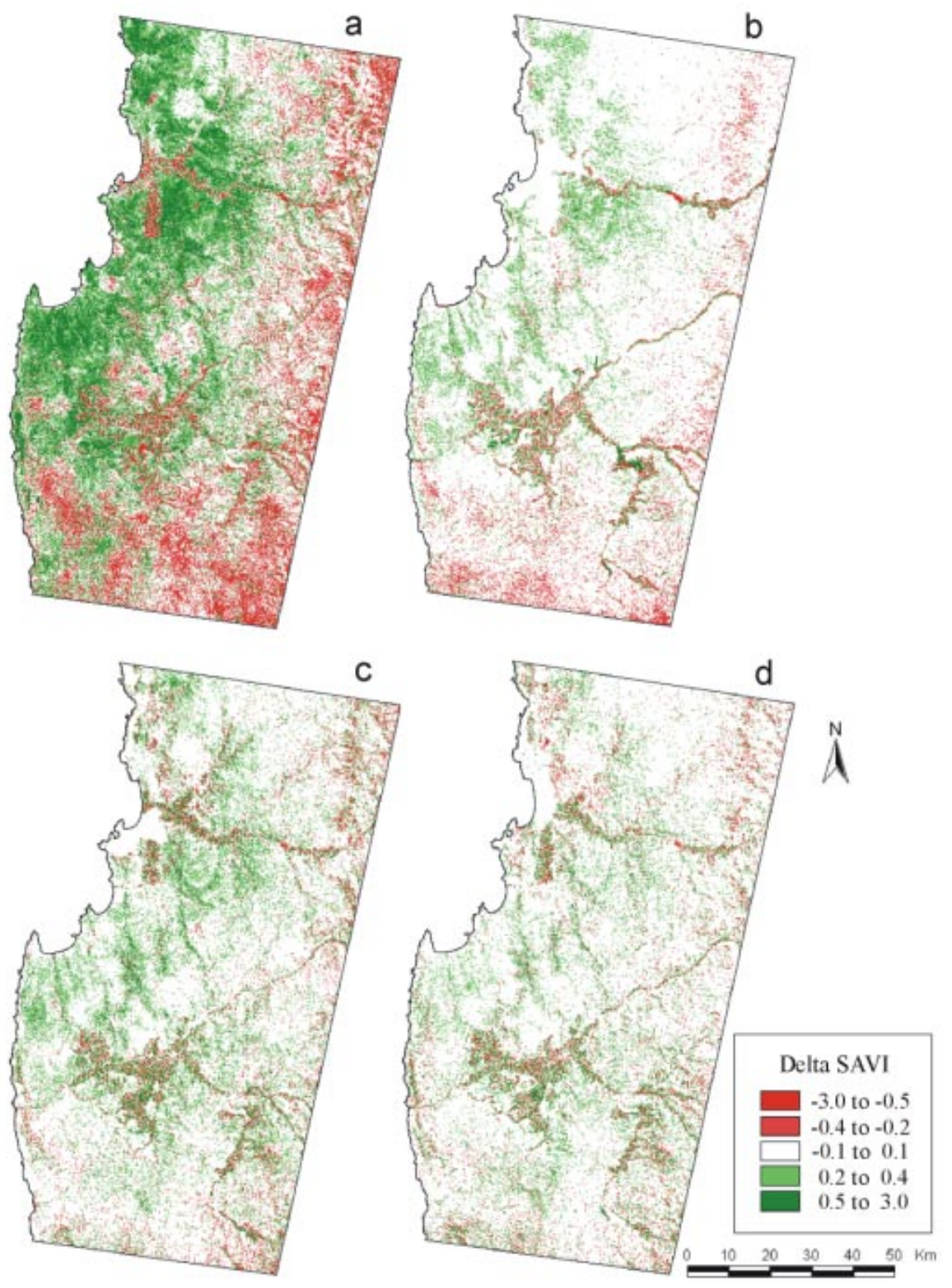

Fig. 2. Satellite productivity difference (delta SAVI) between the rainy and dry year, (a) September (2002-1999), (b) November (2002-1999), (c) January (2003-2000), (d) March (2003-2000).

\section{Results}

\subsection{Satellite productivity estimation}

The delta SAVI calculated from LANDSAT images suggests a change in net primary productivity between dry (1999) and rainy (2002) years at the regional level (Fig. 2). For every month a primary productivity gradient from the coast to the Andes is observed. The differences in productivity (positive or negative) between the dry year and the rainy year were greater in September (spring) and decreased after November. During spring season, as expected, plant productivity in lowland areas increased from La Niña to El Niño conditions (Fig. 2a, b). However, unexpected change occurred in midland areas where plant productivity decreased.

\subsection{The productivity gradient related with elevation}

To calculate a productivity gradient related to elevation, only the dryland areas (shrub and grassland) areas were considered to reduce the artifact that could be due to irrigated and cultivated land. There was a strong inverse correlation between delta SAVI and elevation during the spring (September and November), with a correlation coefficient of $r^{2}=-0.95$, y -0.99 (Fig. 3). Positive productivity at low elevation and negative productivity at high elevation are illustrated. This relationship is decreased during January $\left(r^{2}=-0.88\right)$ and increased during March $\left(r^{2}=0.39\right)$ (Fig. 3). In others terms, at high altitude (near $2500 \mathrm{~m}$ a.s.l.), the primary productivity of the rainy year was less than that of the dry year, during the spring. 


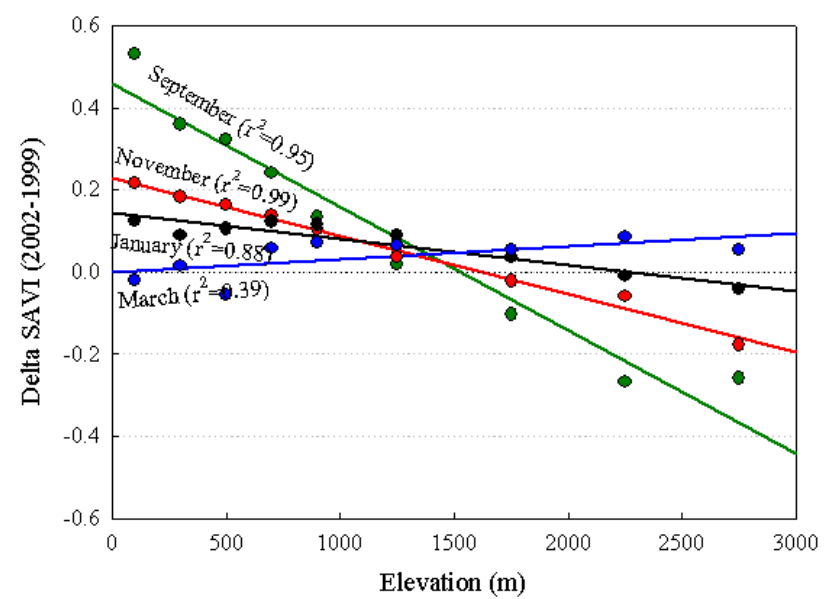

Fig. 3. Relation delta SAVI-Elevation between September (20021999) and March (2003-2000).

\subsection{The temperature gradient related with elevation}

The absolute surface temperature for each elevation range obtained from LANDSAT images was used to compare the temperature gradient with elevation between months (Fig. 4). The use of LANDSAT surface temperatures is an unique solution to calculating temperature in the study area. Existing meteorological stations that measure temperature are concentrated in agricultural areas, out of dryland areas. Temperatures were $\pm 2^{\circ} \mathrm{C}$ of average in low and midelevations in all cases, with maximum temperatures occurring between 1000 and $2000 \mathrm{~m}$ a.s.l. A similar trend is observed in the meteorological data available along the Elqui valley (A. M. Cordova, personal communication). At high elevations, surface temperatures decreased approximately $4^{\circ} \mathrm{C}$ from $1500-2000 \mathrm{~m}$ a.s.l. to $2500-3000 \mathrm{~m}$ a.s.l. in most cases. The exceptions were the spring months in the rainy year of 2002 , with a change close to $-7^{\circ} \mathrm{C}$, suggesting lower temperatures at high elevation during the growth season of 2002 (rainy) compared to the growth season of 1999 (dry). There are no meteorological data available over $2000 \mathrm{~m}$ a.s.l. in the study area during this time to confirm the trend.

Several bio-morphological or functional traits that permit the natural vegetation in this semi-arid zone to resist low water availability (e.g., root system, hydraulic lift, phenological stages) have been studied (Olivares and Squeo, 1999; Squeo et al., 1999; Torres et al., 2002; León and Squeo, 2004), but very few works link these functional traits to air temperature during the favored growth period (Squeo et al., 1996; Rada et al., 1999).

\section{Conclusions}

Comparing data on rainfall, SAVI and surface temperature, we conclude that the limiting factors to vegetation growth are different, based on elevation. Two extremes cases - a La Niña event in 1999 and an El Niño event in 2002 - show that

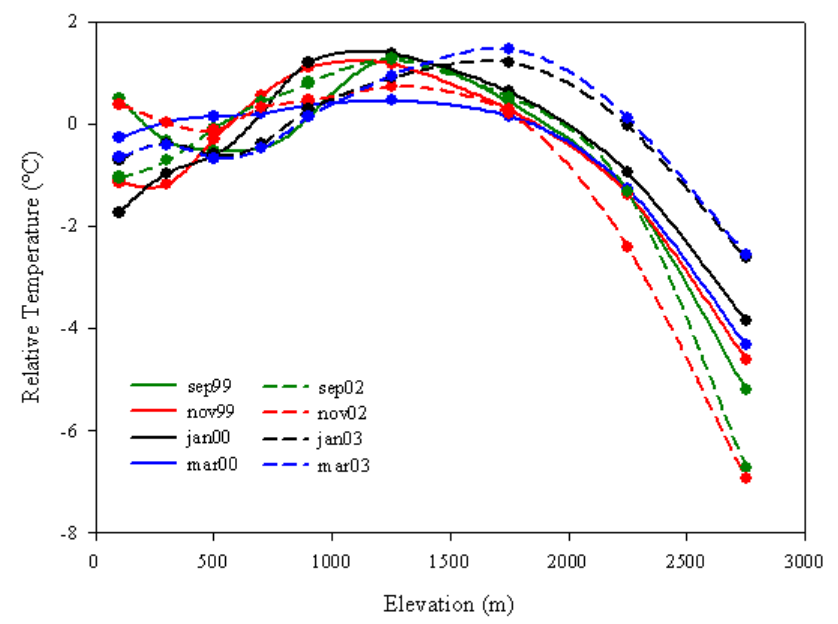

Fig. 4. Adjusted absolute surface temperature (relative temperature) versus elevation for each studied month (between September and March). Each curve was adjusted to the mean temperature of each month (i.e., relative temperature $=$ absolute surface temperature mean temperature).

the increase in water availability during 2002 is the main factor that explains the increase in primary productivity at low elevation. However, the lower temperatures at high elevation (over $2500 \mathrm{~m}$ a.s.l.), associated with high water availability this same year, reduce and delay the net primary productivity in these areas, compared to productivity in a dry year (1999).

Despite the functional traits characteristic of shrubland and grassland vegetation that allow these plants to deal with low water availability, they are sensitive to temperature effects. Therefore, we should ask if other climatic factors controlled by ENSO events could have a significant effect on plant growth.

Acknowledgements. This work was supported by FONDECYT 1030428 and 1030225 funds and the "Compañía Minera del Pacífico". F. A. Squeo and J. R. Gutiérrez thank the support by the BBVA (Spain) Foundation Prize in Research and Conservation Biology.

Edited by: P. Fabian and J. L. Santos

Reviewed by: J. Bendix and M. Richter

\section{References}

Allan, R., Lindesay, J., and Parker, D. (Eds.): El Niño Southern Oscillation and Climatic Variability, Australia: CSIRO, 1996.

Cai, W., McPhaden, M. J., and Collier, M. A.: Multidecadal fluctuations in the relationship between equatorial Pacific heat content anomalies and ENSO amplitude, Geophys. Res. Lett., 31, L01201, doi:10.1029/2003GL018714, 2004.

CONAF: Catastro del Uso del Suelo y Vegetación: IV Región de Coquimbo, CONAF - Gobierno Regional de Coquimbo, Santiago, 32 pp, 2004.

Chander, G. and Markham, B. L.: Revised Landsat 5 TM radiometric calibration procedures and post-calibration dynamic ranges, IEEE Transact. Geosci., 41, 2674-2677, 2003. 
Chavez, P. S.: Image-based atmospheric corrections-revisited and improved, Photogramm. Eng. Remote Sens,, 62, 1025-1036, 1996.

Chuvieco, E.: Fundamentos de Teledetección Espacial, Ediciones Rialp SA, Madrid, 453 pp., 1990.

Dillon, M. O, Rundel, P. W., and Palma, B.: Flora and Vegetation of Pan de Azúcar National Park in the Atacama Desert of Northern Chile, Gayana Botánica, 53, 295-315, 1996.

ESRI: Arcview Spatial Analsysis, Esri Press, Redland, 145 pp., 1996.

ENVI: Exploring ENVI Training Course Manual, Research Systems, Inc., Boulder, 260 pp., 2002.

Holmgren, M., Stapp P., Dickman, C. R., Gracia, C., Graham, S., Gutiérrez, J. R., Hice, C., Jaksic, F., Kelt, D. A., Letnic, M., Lima, M., López, B. C., Meserve, P. L., Milstead, W. B., Polis, G. A., Previtali, M. A., Richter, M., Sabaté, S., and Squeo, F. A.: A synthesis of ENSO effects on drylands in Australia, North America and South America, Adv. Geosci., 6, 69-72, 2006

Huete, A. R.: Extension of soil spectra to the satellite: atmosphere, geometric, and sensors considerations, in: SPECTEL: Propiedades Espectrales y Teledetección de los Suelos y Rocas del Visible al inflarrojo Medio: 163-194, SPECTEL, La Serena, Chile, 1985 .

Huete, A. R.: A soil-adjusted vegetation index (SAVI), Remote Sensing of Environment, 25, 295-309, 1988.

León, M. and Squeo, F. A.: Levantamiento hidráulico: la raíz del asunto, in: Fisiología Ecológica en Plantas: Mecanismos y Respuestas a Estrés en los Ecosistemas, edited by: Cabrera, H. M., Ediciones Pontificia Universidad Católica de Valparaíso, Valparaíso, Chile, 99-109, 2004.

Montecinos, A. and Aceituno, P.: Seasonality of the ENSO-Related Rainfall Variability in Central Chile and Associated Circulation Anomalies, J. Climate, 16, 281-296, 2003.

Olivares, S. and Squeo, F. A.: Patrones fenológicos en especies arbustivas del desierto costero del norte-centro de Chile, Revista Chilena de Historia Natural, 72, 353-370, 1999.

Rada, F., Squeo, F. A., Azócar, A., and Cabrera, H. M.: Water and carbon relations in the genus Adesmia DC. (Papilionaceae) at different altitudes in the high north-central Chilean Andes, Revista Chilena de Historia Natural, 72, 201-211, 1999.

Raed, M. A.: Fundamentos físicos de los sensores remotos, in: Sensores Remotos Aplicados al Estudio de los Recursos Naturales, edited by: Navone, S. M., Ed. Facultad de Agonomía, Universidad de Buenos aires, Buenos Aires, 9-39, 2003.
Richards, J. and Jia, X.: Remote Sensing Digital Image Analysis, Springer, Berlin, 366 pp., 1999.

Rosenthal, Y. and Broccoli, A. J.: In search of Paleo-ENSO, Science, 304, 219-221, 2004.

Squeo, F. A., Rada, F., García, C. E., Ponce, M. E., Rojas, A. L., and Azócar, A.: Cold resistance mechanisms in high desert Andean plants, Oecologia, 105, 552-555, 1996.

Squeo, F. A., Olivares, N., Olivares, S., Pollastri, A., Aguirre, E., Aravena, R., Jorquera, C. B., and Ehleringer, J. R.: Grupos funcionales en arbustos desérticos definidos en base a las fuentes de agua utilizadas, Gayana Botánica, 56, 1-15, 1999.

Squeo, F. A., Arancio, G., and Gutiérrez, J. R. (Eds.): Libro Rojo de la Flora Nativa y de los Sitios Prioritarios para su conservación: Región de Coquimbo, Ediciones Universidad de La Serena, La Serena, 372 pp., 2001.

Squeo, F. A., Gutiérrez, J. R., and Hernández, I. R. (Eds.): Historia Natural del Parque Nacional Bosque Fray Jorge, Ediciones Universidad de La Serena, La Serena, 319 pp., 2004.

Squeo, F. A., Aravena, R., Aguirre, E., Pollastri, A., Jorquera, C. B., and Ehleringer, J. R.: Groundwater dynamics in a coastal aquifer in North-central Chile: Implications for groundwater recharge in an arid ecosystem, Journal of Arid Environments, in press, 2006.

Torres, R., Squeo, F. A., Jorquera, C. B., Aguirre, E., and Ehleringer, J. R.: Evaluación de la capacidad estacional de utilizar eventos de precipitación en tres especies de arbustos nativos con distintos sistemas radiculares, Revista Chilena de Historia Natural, 75, 737-749, 2002.

Trenberth, K.E.: El Niño Definition, Exchanges, Newsletter of the Climate Variability and Predictability Programme (CLIVAR), 1, 6-8, 1996.

Trenberth, K. E.: The Definition of El Niño, Bull. Amer. Meteorol. Soc., 78, 2771-2777, 1997.

Vidiella, P. E., Armesto, J. J., and Gutiérrez, J. R.: Vegetation changes and sequential flowering after rain in the southern Atacama desert, Journal of Arid Environments, 43, 449-458, 1999.

Wolter, K.: The Southern Oscillation in surface circulation and climate over the tropical Atlantic, Eastern Pacific, and Indian Oceans as captured by cluster analysis, J. Climate Appl. Meteor., 26, 540-558, 1987.

Wolter, K. and Timlin, M. S.: Measuring the strength of ENSO how does 1997/98 rank?, Weather, 53, 315-324, 1998. 